Yüzüncü Y1 Üniversitesi
Tarim Bilimleri Dergisi

Araştırma Makalesi (Research Article)

\title{
Sütyemez-1 Ceviz Çeşidinden Açık Tozlanma ile Elde Edilen F1 Bitkilerinin Fenolojik ve Moleküler Karakterizasyonu**
}

\author{
Esra YILDIRIM ${ }^{1}$, Mehmet SÜTYEMEZ ${ }^{* 2}$ \\ ${ }^{1,2}$ Kahramanmaraş Sütçü İmam Üniversitesi, Ziraat Fakültesi, Bahçe Bitkileri Bölümü, 46100, Kahramanmaraş, \\ Türkiye \\ ${ }^{1}$ https://orcid.org/0000-0001-9708-640X ²https://orcid.org/0000-0003-2417-8009 \\ *Sorumlu yazar e-posta:sutyemez@ksu.edu.tr
}

\section{Makale Bilgileri}

Geliş: 18.03 .2020

Kabul: 15.05.2020

Online Yayınlanma 30.06.2020

DOI: 10.29133/yyutbd.706034

\section{Anahtar kelimeler}

Ceviz,

Fenoloji,

ISSR,

Moleküler,

SRAP.
Öz: Bu araştırma, Sütyemez-1 ceviz çeşidinden serbest tozlanma sonucu elde edilen tohumlarla çoğaltılmış genotiplerin birbirleriyle ve ana çeşit ile olan fenolojik ve genetik farklılık seviyelerini belirlemek amacıyla yapılmıştır. Fenolojik olarak, yapraklanma ve yaprak döküm dönemleri incelenmiştir. Genetik farklılıkların belirlenmesinde ise 12 Basit Tekrarlı Diziler Arası Polimorfizm (ISSR) ve 5 Dizi İlişkili Çoğaltılmış Polimorfizm (SRAP) primeri kullanılmıştır. Araştırmada yapraklanma ve yaprak döküm başlangıç özellikleri yönüyle genotiplerin ana çeşide göre genelde daha geç aktif duruma geçtikleri gözlemlenmiştir. Tüm genotiplerde, yapraklanma başlangıç dönemlerinin 60 gün, yaprak döküm başlangıç dönemlerinin ise 44 gün gibi uzun bir periyoda yayıldığı belirlenmiştir. Fenolojik gözlem sonuçları üzerinden ana çeşide göre genotiplerin benzerlik seviyeleri sınıflandırılmıştır. Yapraklanma başlangıç dönemleri yönünden ana çeşide göre genotiplerin, \%18'i “Çok yakın”, \%12'si "Yakın", \%19’u “Orta”, \%18'i “Uzak” ve \%33’ü ise “Çok uzak” kategoride yer almışlardır. Yaprak döküm başlangıç dönemlerine göre ise genotiplerin; \%48'inin "Çok yakın", \%20’sinin "Yakın”, \%25'inin “Orta”, \%3'ünün “Uzak” ve \%4'ünün ise ana çeşide göre "Çok uzak" kategoride yer aldıkları belirlenmiştir. Genetik analizlerde genotiplerin birbirine benzerlik oranının \%50 ile \%99 arasında değiştiği ve polimorfizm oranının \%93.3 olduğu tespit edilmiştir. Araştırmada kullanılan ceviz popülasyonlarının ana bitkiye göre hem fenolojik hem de genetik olarak önemli bir çeşitliliğe sahip olduğu ve bitkisel gen kaynaklarının yönetiminde fenolojik ve moleküler verilerin birlikte kullanılmasının önemli olduğu görülmüştür.

\section{Phenological and Molecular Characterization of Open Pollinated F1 Progenies of Sütyemez-1 Walnut Cultivar}

\section{Article Info}

Received: 18.03.2020

Accepted: 15.05.2020

Online Published 30.06.2020

DOI: 10.29133 /yyutbd.706034

\begin{abstract}
This research was carried out to determine the phenological and genetic difference levels of open-pollinated F1 progenies of Sütyemez-1 cultivar in walnut. Phenologically, leafing and defoliation periods were examined. In determining genetic differences, 12 ISSR and 5 SRAP primers were used. In this study, it was observed that the progenies became active later than their parent in terms of leafing and defoliation initial characteristics. In all progenies, leafing onset periods were determined to extend over a long period of 60 days and defoliation onset periods were 44 days. The classification has been made by considering the results of phenological observations. According to the main cultivar in terms of leafing, 18\% of genotypes are "Very close", 12\% are "Close",
\end{abstract}




\section{Keywords}

Walnut,

Phenological,

ISSR,

Molecular,

SRAP.
19\% are "Medium", 18\% are "Far" and 33\% are "Very Far". According to the first defoliation periods, genotypes; It was determined that $48 \%$ of them were in the category of "Very close", $20 \%$ of them were "Close", $25 \%$ of them were in the "Medium", 3\% were in the "Far" and 4\% were in the "Very Far" category. In genetic analysis, it was determined that the similarity rate of genotypes varied between $50 \%$ and $99 \%$ and the rate of polymorphism was $93.3 \%$. It has been observed that the walnut populations used in the study have a significant diversity both phenologically and genetically compared to the main plant and that it is important to use phenological and molecular data together in the management of plant gene sources.

\footnotetext{
${ }^{* *}$ Bu makale Yüksek Lisans tez çalışmasından elde edilmiştir.
}

\section{Giriş}

Diploit ve 32 kromozoma sahip olan ceviz (Woodworth, 1930) botanik olarak monoik bitkiler grubunda yer alır. Ceviz genotiplerinde çok azda olsa homogami çiçeklenme durumu görülmekle birlikte dikogami çiçeklenme özelliğin yaygındır. Bundan dolayı ceviz çeşitleri çok büyük oranda yabancı tozlanmaktadır. Ceviz bazı meyve türlerine göre hem çoğaltımı hem de yetiştiriciliği bakımından daha uzun zaman ve emek isteyen bir meyve türüdür. Cevizin heterozigot yapıya sahip olması bu türün ismine doğru olarak çoğaltılmasını nerdeyse imkânsız kılmaktadır. Bu durum üretim açısından olumsuz bir etki oluşturmasına karşılık, islahçılar açısından önemli bir genetik varyasyon sağlamaktadır. Ancak cevizin gençlik kısırlığı süresinin uzun olması, 1slah çalışmalarını kısıtlayan diğer bir olumsuz durum olarak değerlendirilmektedir. Son yıllarda biyoteknolojik yöntemlerdeki hızlı ilerleme, sslah süresinin kısalmasına önemli katkılar sunmaktadır.

Bitki ıslahçıları morfolojik ve moleküler markörleri birlikte kullanarak, genetik çeşitliliği belirleme, filogenetik çalışmalar ve genom haritalarının oluşturulması gibi konularda yüksek etkinlikte çalışmalar yapmaktadır (Reddy ve ark., 2002; Ekincialp ve Kazankaya, 2012; Eser ve ark., 2019). ISSR markör tekniği yüksek oranda polimorfizm içermesi, düşük maliyeti, daha kısa zamanda sonuç vermesi, genotiplerin orijinlerinin ve genetik çeşitliliğin belirlenmesi gibi konularda etkili bir şekilde kullanılmaktadır (Potter ve ark., 2002; Pollegioni ve ark., 2003; Christopoulos ve ark., 2010; Malvolti ve ark., 2010). Diziler Arası Çoğaltılmış Polimorfizm (SRAP) primerlerinin sekanslanmasının kolay olması, güvenilirliği, maliyetinin ucuz ve tekrarlanabilirliğinin yüksek olmasından dolayı üstün özelliklere sahiptir.

Ceviz gibi yabancı tozlanan ve heterozigot yapıda olan meyve türlerinde tohumla çoğaltmada elde edilen genotiplerde genetik varyasyonun çok önemli seviyede olduğu bilinmektedir (Özcan ve Sütyemez, 2017). Cevizde çeşit ıslahında geç yapraklanma en önemli fenolojik özelliklerden biridir. Bu yüzden bir ceviz genotipinde, verim, kalite özelliklerinin üstün olması yanında geç yapraklanma ve yaprakların erken dökümülmesi istenir (Tulecke ve McGranahan, 1994; Germain ve ark., 1999; Sütyemez, 2016).

Bu çalışmada, Sütyemez-1 ceviz çeşidinden serbest tozlanma sonucu elde edilen tohumlarla çoğaltılmış genotiplerin, fenolojik özelliklerinin belirlenmesinin yanı sıra ISSR ve SRAP markör teknikleri kullanılarak moleküler karakterizasyonun yapılması ve ana çeşit ile aralarındaki genetik ilişkilerin belirlenmesi amaçlanmıştır.

\section{Materyal ve Yöntem}

Araştırmada, ana çeşit olarak "Sütyemez-1" ve bu çeşide ait serbest tozlanmış tohumlardan elde edilen 95 F1 bitkisi materyal olarak kullanılmıştır.

\subsection{Fenolojik gözlemler}

Araştırmada ceviz genotiplerinin fenolojik farklılıklarını belirlemek amacıyla yapraklanma ve yaprak döküm başlangıçları gibi özellikler IPGRI'de (1994) yer alan parametrelere göre belirlenmiştir (Çizelge 1). 
Çizelge 1. Fenolojik özelliklerin belirlenmesinde kullanılan tanımlamalar

\begin{tabular}{cc}
\hline Özellikler & Tanımlamalar \\
\hline Yapraklanma tarihi & Tepe tomurcuklarının \%50’si patlayarak yeşil yaprakların açığa çıktı̆̆ı \\
tarih \\
Yaprak döküm tarihi & Bitki üzerindeki yaprakların tamamının döküldüğü tarih \\
\hline
\end{tabular}

Kaynak: IPGRI, 1994

\subsection{Moleküler analizler}

$\mathrm{Bu}$ araştırmada, net ve tekrarlanabilir sonuçlar vermesi, birbirine yakın genotipleri daha iyi ayırması, daha uygulanabilir olmasından dolayı ISSR ve SRAP markör teknikleri kullanılmıştır.

Moleküler analizlerde kullanılacak cevizlere ait yaprak örneklerinin genç ve sağlıklı olmasına dikkat edilmiştir. Toplanan yapraklar \%70'lik alkol ile saf sudan geçirilerek kuru buz içerisinde laboratuvara getirilmiş ve DNA izolasyonuna kadar $-80^{\circ} \mathrm{C}$ 'de muhafaza edilmiştir.

Ceviz yapraklarına ait DNA izolasyonu Doyle ve Doyle'nin (1987) geliştirdiği Bardak'ın (2012) modifiye ettiği CTAB protokolüne göre yapılmıştır.

Araştırmada ceviz genotipleri arasındaki genetik farklılıkları belirlemek amacıyla 12 adet ISSR primeri ve 5 adet SRAP primer kombinasyonu Bardak ve Bölek (2012) tarafindan kullanılan ISSR ve SRAP analiz yöntemine göre yapılmıştır. PCR ürünleri \%3'lük agaroz jelde koşturulmuş ve jel görüntüleri ' 1 ' ve ' 0 ' olarak skorlanmıştır. Çalışmada kullanılan primerlerin polimorfizm bilgi içerikleri skorlama sonucunda elde edilen verilere göre Excel'de hesaplanmıştır (Laborda ve ark., 2005). Elde edilen polimorfik bantların ' 1 ' ve ' 0 ' allel toplamları yapılıp her bandın ayrı ayrı allel frekansları aşağıdaki formüle göre hesaplanmıştır. Buradaki $f \mathrm{i}$, i bandının frekansını belirtmektedir.

$$
\mathrm{PIC}=1-\sum \text { (fi) } 2
$$

Araştırmada ceviz genotipleri arasındaki benzerlik katsayısını belirlemek amacıyla Nei (1972) indeksi POPGENE 3.2 paket programında hesaplanmıştır. Genotiplere ait dendogram 'Unwieghted Pair Group of Aritmetic Means' (UPGMA) yöntemine göre NTSYSpc v. 2.02 programı (Rohlf, 1998) kullanılarak Dice indeksine (Dice, 1945) göre oluşturulmuştur.

Ceviz genotiplerine ait kümeleme analizi Structure 2.3.4 paket programı kullanılarak yapılmıştır. İdeal grup sayısını belirlemek için her bir K değeri 10 bağımsız simülasyon ile 1'den 10'a kadar çalıştırılmışıı. Permütasyon modülü ise 10.000 ile 100.000 aralığında seçilmiş ve grup sayısını belirleyen Delta K değeri her bir K değeri için 5 tekrar yapılarak hesaplanmışıı. Analiz sonuçları zip dosyasında arşivlenmiş ve bu dosya "structure harvester" web sayfasına yüklenerek ideal $\Delta \mathrm{K}$ değeri bulunmuştur (Anonim, 2020).

\subsection{Fenolojik ve genetik çeşitliliğin (varyasyon) sınıflandırılması} yapılmıştır.

Ana çeşide göre genotiplerin fenolojik farklılıklarının sınıflandırılması Çizelge 2'ye göre

Çizelge 2. Ana çeşide göre genotiplerin fenolojik farklılıklarının sınıflandırılması

\begin{tabular}{ll}
\hline Sınıflandırma & Sütyemez-1'den (gün olarak) \\
\hline Çok yakın & $\pm 0-4$ \\
Yakın & $\pm 5-9$ \\
Orta & $\pm 10-14$ \\
Uzak & $\pm 15-19$ \\
Çok uzak & \pm 20 ve üzeri \\
\hline
\end{tabular}

*Sütyemez, 2019.

$\mathrm{Bu}$ araştırmada yapılan gözlem ve analizler sonucunda ana çeşit ile ceviz genotipleri arasında çok önemli fenolojik ve moleküler bulgular elde edilmiştir (Çizelge 3; Şekil 2-4). 


\subsection{Fenolojik Gözlemler}

İlkbahar geç donlarından zarar gören meyve türleri için ilk yapraklanma ya da ilk çiçeklenme dönemleri oldukça önemli parametrelerdir. Özellikle geç yapraklanma birçok ceviz islah çalışmasının temel amaçlarından birini oluşturmaktadır. Çalışma kapsamında kullanılan ceviz popülasyonun ilk yapraklanma dönemleri açısından oldukça önemli bir varyasyona sahip olduğu belirlenmiştir. Araştırmada kullanılan ceviz genotiplerinin fenolojik özellikleri ve ana çeşide (Sütyemez-1) göre sınıflandırılmasına ait sonuçlar Çizelge 3'te verilmiştir.

Araştırmada ebeveyn ceviz çeşidinde yapraklanma başlangıcı 19 Mart tarihinde gözlemlenirken, serbest tozlanma ile elde edilen 95 genotipin tamamının ebeveyn çeşide göre farklı tarihlerde yapraklanmaya başladıkları gözlemlenmiştir. Ana çeşide göre yapraklanma başlangıç dönemlerinin sınıflandırılmasında genotiplerin, \%18'inin 'Çok yakın', \%12'sinin 'Yakın', \%19'unun 'Orta' \%18'inin 'Uzak', \%33'ünün ise 'Çok uzak' olduğu belirlenmiştir. Ayrıca ana çeşitte yaprak döküm döneminin 24 Kasım tarihinde başladığı belirlenirken, 11 genotipin ana çeşit ile yaprak döküm dönemlerinin aynı olduğu ve diğer genotiplerin farklı zamanlarda yaprak dökümüne başladıkları tespit edilmiş̧ir. Ana çeşide göre yaprak döküm dönemlerinin sınıflandırılmasında genotiplerin \%48'inin 'Çok yakın', \%20'sinin 'Yakın', \%25'inin 'Orta' \%3’ünün 'Uzak', \%4'ünün ise 'Çok uzak' olduğu belirlenmiştir (Çizelge 3). Ceviz genotiplerinde yapraklanma başlangıç periyodunun 60 güne, yaprak döküm başlangıç periyodunun ise 44 güne yayıldığı belirlenmiştir (Çizelge 3).

Fenolojik olarak yapraklanma ve yaprak döküm başlangıç dönemlerine ait bulgular değerlendirildiğinde ana çeşit ile ceviz genotipleri arasında çok önemli fenolojik varyasyonun olduğu belirlenmiştir.

Sütyemez ve Kaşka (2006) tarafından Kahramanmaraş şartlarında yürütülen çalışmada, 32 adet yerli ve yabancı ceviz genotiplerine ait fenolojik gözlemler incelenmiştir. Genotipler arasından yaprak döküm başlangıç dönemlerinin 23 Kasım ile 15 Aralık tarihleri arasında gerçekleştiği belirlenmiştir. Sütyemez-1 çeşidinin ise 1-8 Aralık tarihleri arasında yapraklarını tamamen dökerek dinlenme dönemine girdiği belirlenmiştir. Bu çalışmada Sütyemez-1 ceviz çeşidinin yaprak döküm başlangıç tarihi 24 Kasım olarak belirlenmiş olup, aradaki farkın iklimsel faktörlerden kaynaklandığı düşünülmektedir.

Bayazit tarafından 2009 yılında Hatay' da yürütülen çalışmada ceviz çeşitlerine ait yapraklanma dönemleri incelenmiştir. Yapraklanma başlangıcı 1 Nisan tarihinde Yalova 4, Şen 1 ve Tokat 1 ceviz çeşitlerinde gerçekleşirken, en geç yapraklanma başlangıcı 7 Nisan'da Yalova 1 çeşidinde gözlemlenmiştir.

Bükücü ve Sütyemez (2016) tarafından Kahramanmaraş şartlarında yapılan çalışmada farklı ceviz çeşit ve genotiplerin fenolojik özellikler belirlenmiştir. Araştırmada "Sütyemez-1" çeşidine ait yapraklanma başlangıç tarihinin 22 Mart olduğu bildirilmiştir. Bu çalışma ise ana çeşit Sütyemez-1 ceviz çeşidine ait yapraklanma başlangıcının 19 Mart tarihinde başladığı görülmektedir (Çizelge 3). Bu özellik yönüyle her iki çalışma sonuçlarının uyum içerisinde olduğu görülmektedir. 
Çizelge 3. Ceviz genotiplerinin fenolojik özellikleri ve ana çeşide (Sütyemez-1) göre sınıflandırılması

\begin{tabular}{|c|c|c|c|c|c|c|c|c|c|}
\hline Genotip 1 & +13 & Orta & +4 & Çok yakın & Genotip 8 & +9 & Yakın & 0 & Çok yakın \\
\hline Genotip 2 & +24 & Çok uzak & -1 & Çok yakın & Genotip 9 & +13 & Orta & -4 & Çok yakın \\
\hline Genotip 3 & +20 & Çok uzak & +15 & Uzak & Genotip 10 & +57 & Çok uzak & +14 & Orta \\
\hline Genotip 4 & +1 & Çok yakın & +10 & Orta & Genotip 11 & +36 & Çok uzak & 0 & Çok yakın \\
\hline Genotip 5 & +19 & Uzak & -10 & Orta & Genotip 12 & +1 & Çok yakın & 0 & Çok yakın \\
\hline Genotip 6 & +26 & Çok uzak & -2 & Çok yakın & Genotip 13 & +13 & Orta & -12 & Orta \\
\hline Genotip 7 & +10 & Orta & +14 & Orta & Genotip 14 & +20 & Çok uzak & +5 & Yakın \\
\hline Genotip 15 & +25 & Çok uzak & +6 & Yakın & Genotip 53 & +2 & Çok yakın & +1 & Çok yakın \\
\hline Genotip 16 & +46 & Çok uzak & -1 & Çok yakın & Genotip 54 & +13 & Orta & 0 & Çok yakın \\
\hline Genotip 17 & +20 & Çok uzak & +9 & Yakın & Genotip 55 & +1 & Çok yakın & -11 & Orta \\
\hline Genotip 18 & +19 & Uzak & +12 & Orta & Genotip 56 & +20 & Çok uzak & -1 & Çok yakın \\
\hline Genotip 19 & +32 & Çok uzak & +10 & Orta & Genotip 57 & +18 & Uzak & +12 & Orta \\
\hline Genotip 20 & +20 & Uzak & +9 & Yakın & Genotip 58 & +19 & Uzak & +10 & Orta \\
\hline Genotip 21 & +20 & Çok uzak & +10 & Orta & Genotip 59 & +2 & Çok yakın & +11 & Orta \\
\hline Genotip 22 & +46 & Çok uzak & +4 & Çok yakın & Genotip 60 & +20 & Çok uzak & 0 & Çok yakın \\
\hline Genotip 23 & +49 & Çok uzak & +5 & Yakın & Genotip 61 & +18 & Uzak & +4 & Çok yakın \\
\hline Genotip 24 & +30 & Çok uzak & +9 & Yakın & Genotip 62 & +2 & Çok yakın & +4 & Çok yakın \\
\hline Genotip 25 & +13 & Orta & +4 & Çok yakın & Genotip 69 & +14 & Orta & +5 & Çok yakın \\
\hline Genotip 26 & +19 & Uzak & +4 & Çok yakın & Genotip 70 & +15 & Orta & +9 & Yakın \\
\hline Genotip 27 & +22 & Çok uzak & +9 & Yakın & Genotip 71 & +3 & Çok yakın & +3 & Yakın \\
\hline Genotip 28 & +19 & Uzak & -1 & Çok yakın & Genotip 72 & +18 & Uzak & +5 & Yakın \\
\hline Genotip 29 & +32 & Çok uzak & +4 & Çok yakın & Genotip 73 & +18 & Uzak & -12 & Orta \\
\hline Genotip 30 & +2 & Çok yakın & +4 & Çok yakın & Genotip 74 & +24 & Çok uzak & +4 & Çok yakın \\
\hline Genotip 31 & +41 & Çok uzak & 0 & Çok yakın & Genotip 75 & +9 & Yakın & -12 & Orta \\
\hline Genotip 32 & +14 & Orta & +3 & Çok yakın & Genotip 76 & +16 & Uzak & -2 & Çok yakın \\
\hline Genotip 33 & +20 & Çok uzak & -1 & Çok yakın & Genotip 77 & +9 & Yakın & -1 & Çok yakın \\
\hline Genotip 34 & +5 & Yakın & -2 & Çok yakın & Genotip 78 & +5 & Yakın & +5 & Yakın \\
\hline Genotip 35 & +8 & Yakın & -1 & Çok yakın & Genotip 79 & +16 & Uzak & -18 & Uzak \\
\hline Genotip 36 & +7 & Yakın & -12 & Orta & Genotip 80 & +14 & Orta & +20 & Çok uzak \\
\hline Genotip 37 & +9 & Yakın & -4 & Çok yakın & Genotip 81 & +3 & Çok yakın & +10 & Orta \\
\hline Genotip 38 & +13 & Orta & -1 & Çok yakın & Genotip 82 & +16 & Uzak & +10 & Orta \\
\hline Genotip 39 & +1 & Çok yakın & -5 & Yakın & Genotip 83 & +3 & Çok yakın & +6 & Yakın \\
\hline Genotip 40 & -1 & Çok yakın & -1 & Çok yakın & Genotip 84 & +14 & Orta & +12 & Uzak \\
\hline Genotip 41 & +9 & Yakın & 0 & Çok yakın & Genotip 85 & +16 & Uzak & +12 & Uzak \\
\hline Genotip 42 & +1 & Çok yakın & -1 & Çok yakın & Genotip 86 & +23 & Çok uzak & +7 & Yakın \\
\hline Genotip 43 & +3 & Çok yakın & 0 & Çok yakın & Genotip 87 & +13 & Orta & +9 & Uzak \\
\hline Genotip 44 & +13 & Orta & -8 & Yakın & Genotip 88 & +9 & Yakın & +11 & Uzak \\
\hline Genotip 45 & +8 & Yakın & +4 & Çok yakın & Genotip 89 & +13 & Orta & +11 & Uzak \\
\hline Genotip 46 & +49 & Çok uzak & -21 & Çok uzak & Genotip 90 & -1 & Çok yakın & +11 & Uzak \\
\hline Genotip 47 & +2 & Çok yakın & 0 & Çok yakın & Genotip 91 & -3 & Çok yakın & 0 & Çok yakın \\
\hline Genotip 48 & +11 & Orta & +9 & Yakın & Genotip 92 & +22 & Çok uzak & +11 & Uzak \\
\hline Genotip 49 & +46 & Çok uzak & +10 & Orta & Genotip 93 & +22 & Çok uzak & -2 & Çok yakın \\
\hline Genotip 50 & +17 & Uzak & +4 & Çok yakın & Genotip 94 & +24 & Çok uzak & +12 & Uzak \\
\hline Genotip 51 & +11 & Orta & +11 & Orta & Genotip 95 & +20 & Çok uzak & +9 & Uzak \\
\hline Genotip 52 & +8 & Yakın & 0 & Çok yakın & $\begin{array}{l}\text { Sütyemez- } \\
1\end{array}$ & - & 0 & 0 & - \\
\hline
\end{tabular}

\subsection{Moleküler analizler}

Ceviz genotipleri arasındaki varyasyonun belirlenmesinde ISSR ve SRAP markör tekniği kullanılmıştır. Çalışmada 12 adet ISSR ve 5 adet SRAP primerleri kullanılmış olup sekizinden (5 ISSR ve 3 SRAP) bant elde edilememiştir. Çalışmada kullanılan 9 primerden 45 adet bant elde edilmiş olup, bu bantların 42 tanesinde polimorfizm görülürken 3 bandın ise monomorfik olduğu belirlenmiştir. Kullanılan primerlere ait polimorfizm bilgi içeriği (PIC) \%51 ile \%99 değerleri arasında farklılık göstermiştir. Çalışmada kullanılan ISSR primerlerine ait polimorfizm oranının \%93.3 olduğu belirlenmiştir. Araştırma sonucunda en fazla allel (7) üreten primerin ISSR 11 olduğu tespit edilerek, ortalama allel sayısı ise 4.6 olarak hesaplanmıştır (Çizelge 4). 


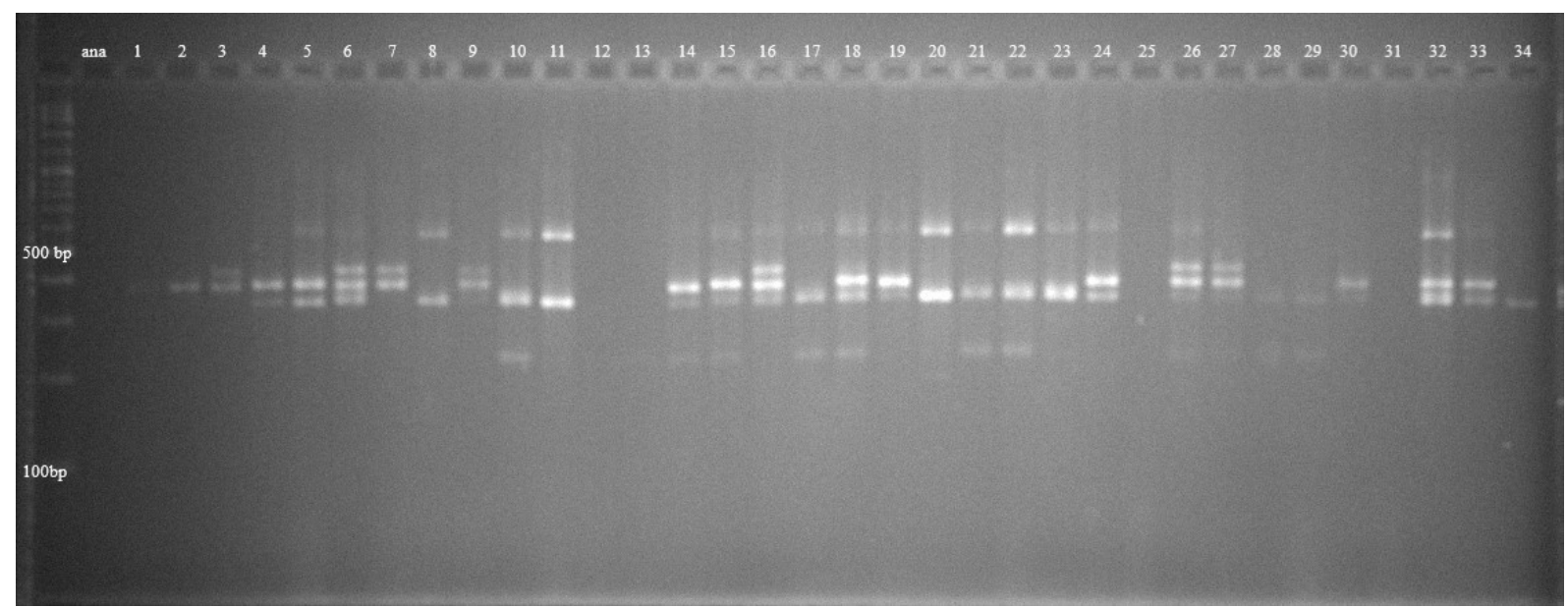

Şekil 1. ISSR 13 primerine ait bantların görünümü.

Potter ve ark. (2002) tarafından 48 adet ceviz (Juglans regia) çeşidi üzerinde ISSR markör tekniği kullanılarak çeşitler arasındaki genetik ilişkiler incelenmiştir. Yapılan bu çalışmada 8 adet ISSR primerinin sonucunda 54 bant elde edilmiş ve elde edilen bantların 31'inin (\%57) polimorfizm olduğu belirlenmiştir. Araştırmacılar, ISSR primerlerinin ceviz çeşit ve genotipleri arasındaki genetik farklılıkların belirlenmesinde, RAPD tekniğine göre daha fazla polimorfik bant oluşturduğunu bildirmişlerdir. Farklı araştırıcılar tarafindan ceviz çeşit ve genotiplerinde ISSR tekniği kullanılarak yapılan çalışmalarda polimorfizm oranlarının \%43 ile \%72 arasında değiştiği belirtilmektedir (Potter ve ark., 2002; Akcan, 2007; Pollegioni ve ark., 2008; Doğan ve ark., 2014; Najafi ve ark., 2014).

Kafkas ve ark. (2005) tarafindan yapılan çalışmada 21 ceviz çeşit ve genotipinde 6 AFLP ve 2 SAMPL primer kombinasyonu kullanılmış, \%50.4'ü polimorfik olmak üzere toplam 230 bant elde edilmiştir. Çalışmada Maraş-18 ile Maraş-46; KSÜ-5 ile Sütyemez-1; Maraş-12 ile Sütyemez-2; Kaman-3 ile Kaman-4 ve KSÜ-11 ile Maraş-10 genotiplerinin yakın akraba oldukları saptanmıştır. Çalışma sonucunda, SAMPL tekniğinin AFLP tekniğine göre cevizde akraba genotiplerin ayırımında daha iyi sonuç verdiği belirtilmiştir.

Çizelge 4. Çalışmada kullanılan ISSR primerlerinin allel sayıları ve PIC (polimorfizm bilgi içeriği) değerleri

\begin{tabular}{ccccc}
\hline Say1 & Primer ad1 & Baz dizilimi & Allel sayıs1 & PIC \\
\hline 1 & ISSR 5 & CACACACACACAG & 4 & 0.99 \\
2 & ISSR 6 & CACACACACACACAGT & 4 & 0.95 \\
3 & ISSR 8 & ACACACACACACACACACC & 6 & 0.99 \\
4 & ISSR 9 & ACACACACACACACACTG & 4 & 0.99 \\
5 & ISSR 11 & GAGAGAGAGAGAGAGATC & 7 & 0.96 \\
6 & ISSR 12 & GAGAGAGAGAGAGAGAGAC & 4 & 0.51 \\
7 & ISSR 13 & AGAGAGAGAGAGAGAGC & 6 & 0.99 \\
8 & EM7 (F) & GACTGCGTACGAATTCAA & 4 & 0.99 \\
& ME5 (R) & TGAGTCCAAACCGGAAG & & \multirow{2}{*}{0.85} \\
\hline
\end{tabular}

Bu araştırmada, ceviz genotiplerine ait genetik varyasyon, Nei’ye (1972) göre hesaplanmıştır. ISSR ve SRAP analizleri sonucu oluşturulan dendrogram (Şekil 2) incelendiğinde, genotipler arasındaki genetik benzerlik oranının \%50 ile \%99 arasında değişim gösterdiği belirlenmiştir.

Ceviz genotipleri arasındaki geniş benzerlik indeks aralığı beklenen bir durumdur. Çünkü ceviz bitkisinde yaygın olarak görülen dikogami nedeniyle genotipler arasında genetik varyasyonun yüksek olması beklenen bir sonuçtur.

Doğan ve ark. (2014) tarafindan yürütülen bir araştırmada, yerli ve yabancı kökenli 62 ceviz çeşidi arasındaki genetik benzerliği belirlemek amacı ile ISSR ve RAPD markör tekniklerine ait 25 'er 
primer, tüm ceviz çeşitlerine uygulanmıştır. Markörlere ait genetik benzerlik katsayısının ISSR tekniğinde 0.62 ile 0.94 olduğu belirlenirken, RAPD tekniğinde ise bu değerin 0.63 ile 0.95 arasında yayılım gösterdiği belirlenmiştir. Ayrıca yapılan çalışma sonucunda ISSR ve RAPD markör tekniklerinin çeşitler arasındaki genetik benzerliği belirlemede benzer sonuçlar vermesine rağmen ISSR tekniğinin RAPD tekniğine göre tekrarlanabilirlik açısından daha üstün özelliklere sahip olduğu belirlenmiştir.

Orman (2018) tarafından Atatürk Bahçe Kültürleri Merkez Araştırma Enstitüsü’nde yürütülen çalışmada 42 adet yerli ceviz genotipleri ISSR primerleri ile taranmış ve benzerlik oranları $\% 21$ ile \%83 arasında değişim gösterdiği belirtilmiştir.

Cevizde, değişik genotipler üzerinde yapılan genetik çalışmada genotipler arasındaki benzerlik indekslerinin Akcan'a (2007) göre 0.60 ile 0.93 arasında, Ahmed ve ark.'na (2012) göre \%12 ile \%79 arasında Najafi ve ark.'na (2014), göre 0.47 ile 0.88 arasında, ve Vahdati ve ark.'na (2015) göre 0.56 ile 0.82 arasında değiştiği belirtilmiştir.

Ceviz genotiplerinin ana çeşit ve kendi aralarındaki moleküler düzeyde farklılıklarının belirlenmesinde kullanılan UPGMA (Unweighed Pair Group Method of Aritmetic Averages), NTSYSpc ver. 2.2 ve Structure 2.3.4 programlarından elde edilen bulgular Şekil 3-Şekil 5'de verilmiştir.

Elde edilen ISSR ve SRAP analiz sonuçlarına göre 95 ceviz genotipinin 2 ana gruba ayrıldığ 1 belirlenmiş olup bu ana gruplarda kendi içerisinde birbirinden farklı gruplar oluşturmuştur (Şekil 2). Genetik olarak, ana çeşit ile 55 genotipin aynı grupta kümelendiği, 40 genotipin ise diğer grupta yer aldığ 1 tespit edilmiştir.

İpek ve ark. (2019) tarafından selekte edilen 8 ceviz genotipinin ISSR tekniği kullanılarak bazı önemli ceviz çeşitleri ile genetik benzerlikleri incelenmiştir. Oluşturulan UPGMA dendogramında en yüksek genetik benzerliğin 0.491 ile 0.891 arasında değiştiği bildirilmiştir.

Orman ve ark. (2017) tarafindan Genetik çeşitliliğini tespit etmek için yapılan bir çalışmada, Türkiye'nin değişik bölgelerinden toplanan 154 ceviz genotip üzerinde, Dizileyerek Genotipleme (GBS) işaretleyicileri kullanılmıştır. GBS işaretleme yöntemi toplamda 16.767 SNP (tek nükleotit polimorfizm) markörü üretmiş olup, filtreleme işleminden sonra ceviz genotiplerinin genetik çeşitlilik analizi için 13.611 adet polimorfik SNP markörü kullanılmıştır. Elde edilen temel bileşenler analizi sonuçları, çalışmada yer alan 154 ceviz genotipinin üç gruba ayrıldığını ortaya koymuştur. Çalışmadan elde edilen bilgiler 1şı̆̆ında, GBS işaretleyicilerin ceviz genotiplerinin çeşitlilik analizi ve değerlendirilmesinde etkili olarak kullanılabileceği vurgulanmıştır.

$\mathrm{Bu}$ araştırmaya ait genetik bulgular üzerinden Structure 2.3.4 programında ideal $\mathrm{K}$ değeri hesaplanarak diyagram elde edilmiştir (Şekil 3). Genotipler arasındaki genetik farklılı̆̆ 1 belirlemek amacıyla tekrar Structure 2.3.4 programında kümeleme analizi yapılmıştır. Şekil 4'teki kümeleme analizi sonucunun 2 farklı renk ile temsil edilmesi, genotiplerin 2 ana gruba ayrıldığını ifade etmektedir (Şekil 3; Şekil 4). İstatistiksel değerlendirilme amacıyla yapılan dendogram ve kümeleme analiz sonuçlarının birbiriyle tutarlık içerisinde olduğu görülmektedir. 


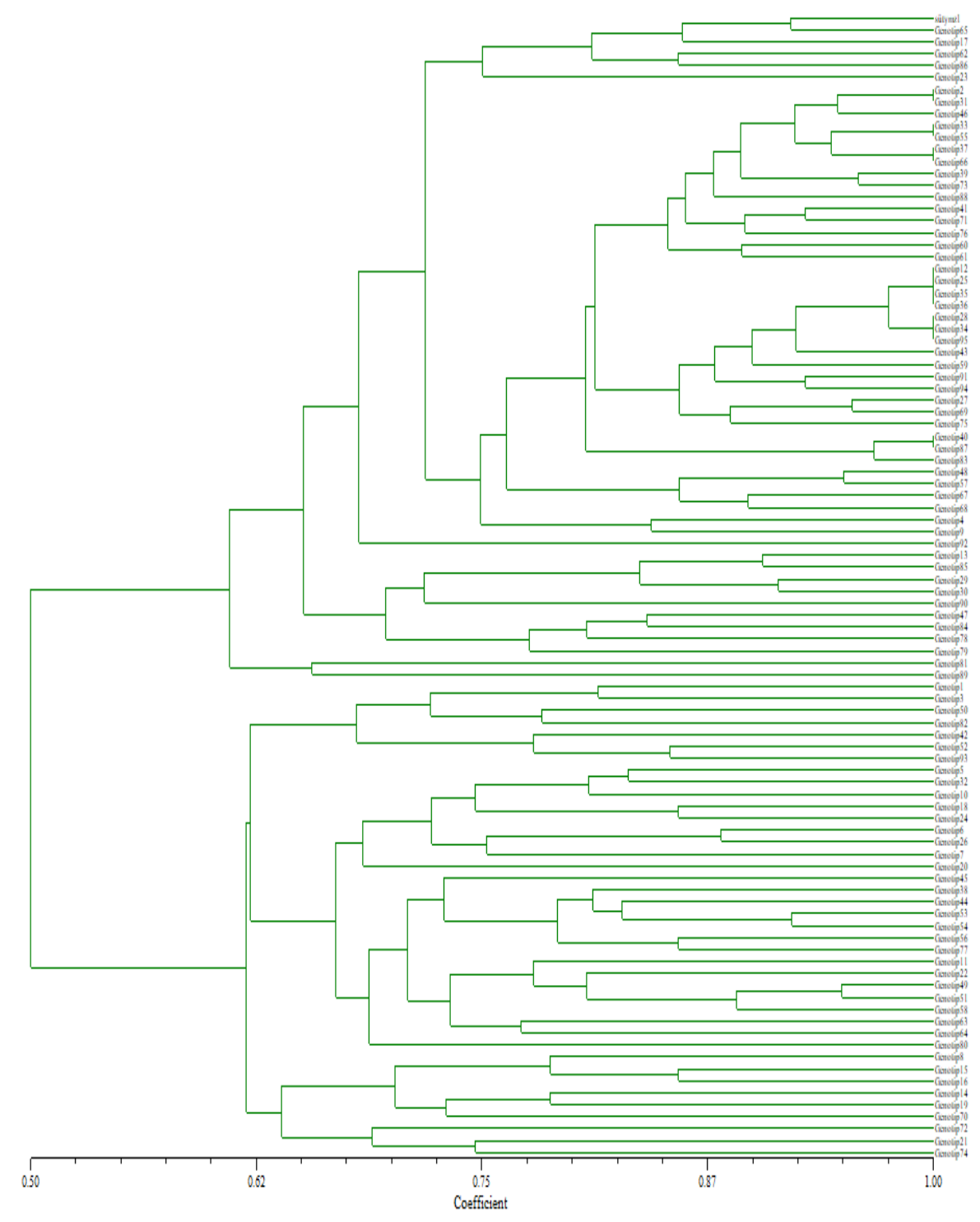

Şekil 2. ISSR ve SRAP moleküler markör teknikleri ile oluşturulan ana çeşit ve 95 genotipe ait genetik benzerlik dendogramı.

Şekil 3. ISSR ve

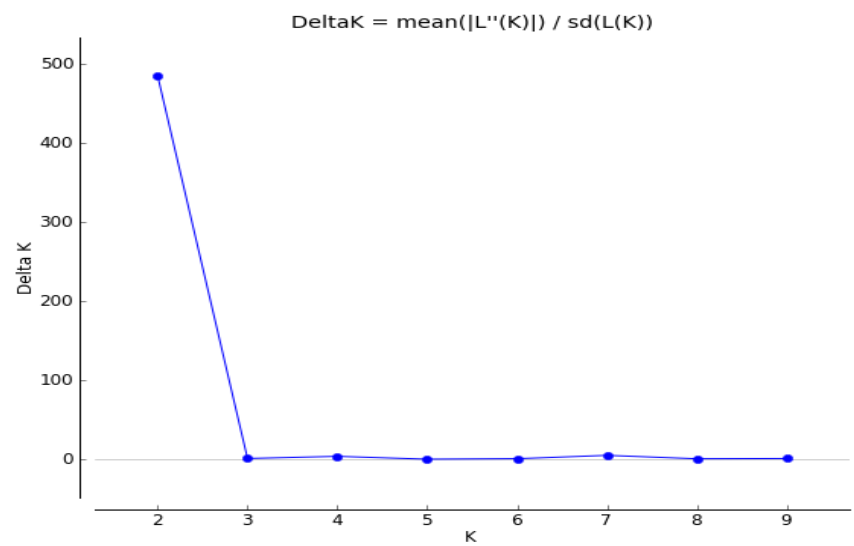

SRAP moleküler

markör teknikleri ile oluşturulan ana çeşit ve 95 genotipe ait Structure programında elde edilen ideal $\Delta \mathrm{K}$ değeri. 


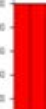

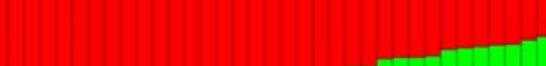

Şekil 4. ISSR ve SRAP moleküler markör teknikleri ile oluşturulan ana çeşit ve 95 genotipe ait kümeleme analiz sonuçları $(\Delta \mathrm{K}=2)$.

\section{Sonuç}

$\mathrm{Bu}$ araştırmada ana çeşitten serbest tozlanma ile elde edilmiş ceviz genotipleri ve Sütyemez-1 arasındaki fenolojik ve genetik ilişkiler ortaya çıkarılmıştır. Her iki yöntemden de elde edilen veriler ayrı ayrı değerlendirilerek karşılaştırılmıştır.

Araştırmada Sütyemez-1 ceviz çeşidinin tohumlarından elde edilen genotiplerin hem ana çeşit ile hem de kendi aralarında, fenolojik ve genetik olarak önemli bir varyasyonun olduğu tespit edilmiştir.

Ana (ebeveyn) çeşit ve genotiplerin fenolojik gözlemleri mukayese edildiğinde genelde genotiplerin ana çeşide göre yapraklanma ve yaprak döküm dönemlerine daha geç girdiği belirlenmiştir. $\mathrm{Bu}$ durum melezleme sslah programlarında Sütyemez-1 çeşidinin ana ebeveyn olarak tercih edilmesi yönünde önemli bir bulgu olarak değerlendirilebilir.

Gen kaynaklarının yönetiminde morfolojik ve moleküler verilerin birlikte kullanılmasının daha net bir karakterizasyon sağlayabileceği, ceviz (Juglans regia L.) meyve türünde yakın akraba olan genotiplerde genetik farklılıkları belirlemek amacıyla ISSR ve SRAP primerlerinin güvenli bir şekilde kullanılabileceği belirlenmiştir.

$\mathrm{Bu}$ çalışma ceviz meyve türünde tohumla çoğaltma durumunda fenolojik ve genetik açılım düzeyinin ortaya konulmasının öneminin yanında bundan sonra yapılacak ıslah çalışmalarına kaynak sunması yönüyle de oldukça önemlidir.

\section{Teșekkür}

Kahramanmaraş Sütçü İmam Üniversitesi Bilimsel Araştırma Projeleri Birimi’ne bu çalışmaya verdiği destekten dolayı teşekkürlerimi sunarım.

\section{Kaynakça}

Ahmed, N., Mir, J. I., Mir, R. R., Rather, N. A., Rashid, R., Wani, S. H., \& Sheikh, M. A. (2012). SSR and RAPD analysis of genetic diversity in walnut (Juglans regia L.) Genotypes from Jammu and Kashmir, India. Physiology and Molecular Biology of Plants, 18(2), 149-160.

Agarwal, M., Shrivastava, N., \& Padh, H. (2008). Molecular marker techniques and their applications in plant sciences. Plant Cell Reports 27, 617-631.

Anonim, (2020). http://taylor0.biology.ucla.edu/structureHarvester/

Akcan, S. (2007). Kaman cevizlerinde apomiksis özelliğinin moleküler yöntemlerle araștırılması. Yüksek Lisans Tezi. Adana Çukurova Üniversitesi Fen Bilimleri Enstitüsü. Adana. 93s.

Bardak, A. (2012). Lif ve hav oluşumuyla ilişkili DNA markörlerinin pamuk (Gossypium hirsutum L.) genomunda haritalanması ve QTL analizi. Doktora Tezi. Kahramanmaraş Sütçü İmam Üniversitesi Fen Bilimleri Enstitüsü. Kahramanmaraș. 141s.

Bardak, A., \& Bölek, Y. (2012). Genetic diversity of diploid and tetraploid cottons determined by SSR and ISSR Markers, Turkish Journal of Field Crops, 17(2), 139-144.

Bayazit, S. (2011). Bazı ceviz (Juglans regia L.) genotiplerinin Yayladağı (Hatay) koşullarındaki fenolojik özellikleri ve yan dal verimliliği. Atatürk Üniversitesi Ziraat Fakültesi Dergisi, 42(2), 95-102.

Bükücü, Ş.B., \& Sütyemez, M. (2016). The determination of the chilling requirements of some walnut juglans regia L cultivars and types. Turkish Journal of Agricultural and Natural Sciences, Vol. 3, no. 4, pp. 305-310.

Christopoulos, M.V., Rouskas, D., Tsantili, E., \& Bebeli, P.J. (2010). Germplasm diversity and genetic relationships among walnut (Juglans regia L.) cultivars and greek local selections revealed by inter-Simple Sequence Repeat (ISSR) markers. Scientia Horticulturae, 125(4), 584-592. 
Dice, L.R. (1945). Measures of the amount of ecologic association between species. Ecology, 26, 297302.

Doğan, Y., Kafkas, S., Sütyemez, M., Akça, Y., \& Türemiş, N. (2014). Assessment and characterization of genetic relationships of walnut (Juglans regia L.) genotypes by three types of molecular markers. Scientia Horticulturae, 168, 81-87.

Doyle, J.J. \& Doyle, J.L. (1987). A Rapid DNA Isolation procedure for small quantities of fresh leaf tissue. Phytochemical Bulletin, 19, 11-15.

Ekincialp, A.,\& Kazankaya, A. (2012). Hakkâri yöresi kuşburnu genotiplerinin (Rosa spp.) bazı fiziksel ve kimyasal özelliklerinin belirlenmesi. Yüzüncü Yıl Üniversitesi Tarım Bilimleri Dergisi, 22(1), 7-11.

Eser, E., Topçu, H., Kefayat1, S., Sütyemez, M., Islam M.R., \& Kafkas, S. (2019). Highly polymorphic novel simple sequence repeat markers from class 1 repeats in walnut Juglans regia L., Turkish Journal of Agriculture and Forestry, vol. 43, pp. 174-183.

Germain, E., Prunet, JP., \& Garcin, A. (1999). Le noyer, monographie. CTIFL.

IPGRI (1994). Walnut Descriptors for Walnut (Juglans Spp.). International Plant Genetic Resources Institute, Rome, Italy.

Ipek, M., Arıkan, Ş., Pırlak, L., \& Eşitken, A. (2019). Phenological, morphological and molecular characterization of some promising walnut (Juglans regia L) genotypes in Konya. ErwerbsObstbau, 61(2), 149-156.

Kafkas, S., Ozkan, H., \& Sutyemez, M. (2005). DNA polymorphism and assessment of genetic relationships in walnut genotypes based on AFLP and SAMPL markers. Journal of the American Society for Horticultural Science, 130(4), 585-590.

Laborda, P.R., Oliveira, K.M., Garcia, A.A., Paterniani, M.E., \& De Souza, A.P. (2005). Tropical maize germplasm: what can we say about its genetic diversity in the light of moleculer markers. Thear Appl Genetik, 111(7), 1288- 1299.

Malvolti, M. E., Pollegioni, P., Bertani, A., Mapelli, S., \& Cannata, F. (2010). Juglans regia provenance research by molecular, morphological and biochemical markers: a case study in Italy. Biorem. Biodiv. Bioavail, 4, 84-92.

Najafi, F., Mardi, M., Fakheri, B., Pirseyedi, S. M., Mehdinejad, N., \& Farsi, M. (2014). Isolation and characterization of novel microsatellite markers in walnut (Juglans regia L.). American Journal of Plant Sciences. 5(03), 409-415.

Nei, M. (1972). Genetic Distance Between Populations. The American Naturalist, 106, 283-292.

Orman, E., Ates, D., Nemli, S., \& Tanyolaç, B. (2017). Analysis of genetic diversity among walnut genotypes in turkey revealed by GBS markers. International Green Biotechnology Congres. September 11-13, 2017, İstanbul, Turkey

Orman, E., (2018). Bazı yerli ceviz genotiplerinin (Juglans regia L.) agromorfolojik ve moleküler olarak tanımlanması. Doktora tezi. Ege Üniversitesi Fen Bilimleri Enstitüsü Bahçe Bitkileri Ana Bilim Dal1.

Özcan, A., \& Sütyemez, M. (2017). Bazı ceviz Juglans regia L. çeşitlerinin çimlenme ve çögür anaçlık gelişme performanslarının belirlenmesi, KSU Journal. Natural. Scince, vol. 20, no. 1, pp. 75-79.

Pollegioni P., Bartoli S., Cannata F., \& Malvolti M.E. (2003). Genetic differentiation of four italian walnut (Juglans regia L.) varieties by inter simple sequence repeat (ISSR). J Genet Breed., 57, 231-240.

Pollegioni, P., Woeste, K., Binbaǵ, A., Mugnozza, G., Scarascia, \& Malvolti, M.E. (2008). Characteristics of Juglans nigra (L), Juglans regia (L) and Juglans X Intermediate (Carr.) SSR Markers: A case study in Italy. Silvae Genetica, 58(1-2), 68-78.

Potter, D., Gao, F., Aiello, G., Leslie, C., Mc. \& Granahan, G.H. (2002). Intersimple sequence repeat markers for fingerprinting and determining genetic relationships of walnut (Juglans regia) cultivars. J. Amer. Soc. Hort. Sci., 127(1), 75-81.

Reddy, M.P., Sarla, N., \& Siddiq, A. (2002). Inter Simple Sequence Repeat (ISSR) polymorphism and its application in plant breeding. Euphytica, 128, 9-17.

Rohlf, F.J. (1998). NTSYSpc Numerical Taxonomy and Multivariate Analysis System Version 2.0 User Guide. 
Sütyemez, M., \& Kaşka, N. (2006). Comparison of the behaivours of some localy selected genotypes and local and foreign walnut cultivars under K. Maras ecological conditions, Acta, no. 705, pp. 151-157.

Sütyemez, M. (2016). New walnut cultivars Maras 18 Sutyemez 1 and Kaman 1, HortScience, vol. 51, no. 10, pp. 1301-1303.

Sütyemez, M. (2019). Bitki Islahı Ders Notları (Yayınlanmamış).

Tulecke W, \& McGranahan G. (1994). The Walnut Germplasm Collection of the University of California, Davis. A Description of the Collection and a History of the Breeding Program of Eugene F. Serr and Harold I. Forde. Report No. 13. University of California, Genetic Resources Conservation Program, Davis,

Vahdati, K., Pourtaklu, S. M., Karimi, R., Barzehkar, R., Amiri, R., Mozaffari, M., \& Woeste, K. (2015). Genetic diversity and gene flow of some Persian walnut populations in southeast of Iran revealed by SSR markers. Plant Systematics and Evolution, 301(2), 691-699.

Woodworth, R.H. (1930). Meiosis of microsporogenesis in the Juglandaceae. American Journal of Botany, 9, 863-869. 